\title{
Characterization of a thermostable archaeal polynucleotide kinase homologous to human Clp1
}

\author{
RUCHI JAIN ${ }^{1}$ and STEWART SHUMAN ${ }^{2}$ \\ ${ }^{1}$ Graduate Program in Chemical Biology, Sloan-Kettering Institute, New York, New York 10065, USA \\ ${ }^{2}$ Molecular Biology Program, Sloan-Kettering Institute, New York, New York 10065, USA
}

\begin{abstract}
Clp1 proteins are essential components of the eukaryal mRNA 3' cleavage-polyadenylation machinery. Human Clp1 has an additional function as an RNA-specific 5'-OH polynucleotide kinase, which is implicated in RNA end healing. Yeast Clp1 has no kinase activity, although it binds ATP. Here we report that Clp1-like proteins are extant in archaea. Purification and characterization of Pyrococcus horikoshii Clp1 (PhoClp1) reveals it to be a thermostable 5' -OH polynucleotide kinase optimally active at $55^{\circ} \mathrm{C}$ to $85^{\circ} \mathrm{C}$. PhoClp1 catalyzes transfer of the gamma phosphate from ATP $\left(K_{\mathrm{m}} 16 \mu \mathrm{M}\right)$ to either $5^{\prime}$-OH RNA or DNA ends, although it prefers RNA in a competitive situation. Increasing the monovalent salt concentration to $250 \mathrm{mM}$ suppresses the DNA kinase without affecting RNA phosphorylation, suggesting that RNA is a likely substrate for this enzyme in vivo. Indeed, we show that expression of PhoClp1 in budding yeast can complement a lethal mutation in the 5'-OH RNA kinase module of tRNA ligase. PhoClp1 is a member of the P-loop phosphotransferase superfamily. Alanine mutations at the P-loop lysine (Lys49) and a conserved aspartate (Asp73) inactivate the kinase. Our studies fortify emerging evidence for an enzymatic RNA repair capacity in archaea and provide a new reagent for polynucleotide phosphorylation at high temperatures.
\end{abstract}

Keywords: RNA end healing; phosphotransferase; tRNA splicing

\section{INTRODUCTION}

Polynucleotide kinases and polynucleotide ligases catalyze the end healing and end sealing steps of nucleic acid repair pathways. The need for enzymes that remodel DNA or RNA ends prior to ligation arises from the requirement for $3^{\prime}-\mathrm{OH}$ and $5^{\prime}-\mathrm{PO}_{4}$ termini as substrates to regenerate a $3^{\prime}-5^{\prime}$ phosphodiester linkage (Pascal 2008). Thus, when breakage directly generates a $5^{\prime}-\mathrm{OH}$ end, or when a phosphatase converts a $5^{\prime}-\mathrm{PO}_{4}$ to a $5^{\prime}-\mathrm{OH}$, the ends cannot be sealed. This problem is solved by polynucleotide kinase (Pnk), which transfers the gamma phosphate from an NTP donor to the $5^{\prime}-\mathrm{OH}$ RNA or DNA acceptor to form a $5^{\prime}-\mathrm{PO}_{4}$ product. Ligation is not the only transaction that relies on a $5^{\prime}-\mathrm{PO}_{4}$ end. RNA interference entails recognition of the $5^{\prime}-\mathrm{PO}_{4}$ moiety of the instructive small interfering RNA (Nykänen et al. 2001; Chiu and Rana 2002). RNA turnover by eukaryal $5^{\prime}-3^{\prime}$ exonucleases of the Xrn1 family also depends on a 5'$\mathrm{PO}_{4}$ end (Stevens 2001).

Reprint requests to: Stewart Shuman, Molecular Biology Program, Sloan-Kettering Institute, New York, NY 10065, USA; e-mail: s-shuman@ ski.mskcc.org; fax (212) 772-8410.

Article published online ahead of print. Article and publication date are at http://www.rnajournal.org/cgi/doi/10.1261/rna.1492809.
Bacteriophage T4 Pnk is the exemplary end healing enzyme (Richardson 1965; Novogrodsky and Hurwitz 1966; Novogrodsky et al. 1966). T4 Pnk is equally adept at phosphorylating DNA or RNA ends, a property that has been exploited for the past 40 years for DNA/RNA end labeling, sequencing, and molecular cloning. The biological function of T4 Pnk is as an RNA repair enzyme; it acts in tandem with T4 RNA ligase 1 to heal and seal tRNA breaks (Amitsur et al. 1987; Schwer et al. 2004; Nandakumar et al. 2008). The structure and catalytic mechanism of T4 Pnk have been elucidated (Wang and Shuman 2001, 2002; Galburt et al. 2002; Wang et al. 2002; Eastberg et al. 2004). Pnk is a member of the P-loop phosphotransferase superfamily, which is defined by a signature NTP-binding motif and a conserved fold. Pnk homologs with analogous roles in tRNA end healing comprise part of the multifunctional yeast and plant tRNA splicing enzymes (Wang et al. 2006). By contrast, the mammalian Pnk homolog is dedicated to DNA end healing (Bernstein et al. 2005). Pnk enzymes have also been characterized from other sources, including diverse bacterial viruses (Zhu et al. 2004; Blondal et al. 2005), a eukaryal baculovirus (Martins and Shuman 2004), and two bacteria: Clostridium thermocellum and Deinococcus radiodurans (Martins and Shuman 2005; Blasius et al. 2007). 
An RNA-specific Pnk was isolated from human cells 30 years ago (Shuman and Hurwitz 1979), at which time it was speculated that the RNA kinase might function in tRNA splicing. Weitzer and Martinez (2007) recently assigned the RNA kinase activity to the human Clp1 protein, a component of the eukaryal mRNA 3' cleavage/polyadenylation apparatus (de Vries et al. 2000; Minvielle-Sebastia et al. 1997; Gross and Moore 2001). Purified recombinant human Clp1 displays RNA-specific Pnk activity in vitro (Weitzer and Martinez 2007) and is able to genetically complement inactivating mutations in the Pnk domain of yeast and plant tRNA ligase (Ramirez et al. 2008), making a strong case that human Clp1 can act as an RNA repair enzyme. It remains to be determined whether Clp1 is essential for tRNA splicing in mammalian cells. Clp1 is conserved in budding yeast and is required for mRNA 3' end formation. The crystal structure of yeast Clp1 bound to ATP verified that Clp1 is a member of the P-loop superfamily (Noble et al. 2007), albeit with defining structural elements not found in T4 Pnk. Despite its similarity to human Clp1, yeast Clp1 has no detectable Pnk or NTP phosphohydrolase activities (Noble et al. 2007; Ramirez et al. 2008). These findings raise interesting questions about the evolution and functional specification of the eukaryal Clp1 protein clade.

We focus here on archaea as a possible source of an ancestral Clp1. Archaea and eukarya have a number of common features with respect to their DNA and RNA informational pathways. tRNA splicing is extant in all known archaea, and the available evidence suggests that archaea and mammals share a tRNA splicing mechanism of direct ligation of $2^{\prime}, 3^{\prime}$ cyclic phosphate and $5^{\prime}-\mathrm{OH}$ ends (Filipowicz and Shatkin 1983; Filipowicz et al. 1983; Laski et al. 1983; Zofallova et al. 2000; Salgia et al. 2003). This tRNA splicing pathway, which does not involve RNA 5' end phosphorylation, differs completely from the splicing pathway of yeast and plants that requires an RNA 5' kinase. None of the enzymes responsible for the archaeal/ mammalian mechanism have been identified, and it is possible that a yeast/ plant-like RNA sealing pathway might coexist in archaea with the direct ligation pathway, as seems to be the case in metazoa (Zillman et al. 1991). Recent studies highlight the existence of a novel subfamily of $3^{\prime}-\mathrm{OH} / 5^{\prime}-\mathrm{PO}_{4}$ RNA ligases in archaea (Ho and Shuman 2002; Torchia et al. 2008; Brooks et al. 2008), which raises the prospect that archaea might have an end healing pathway tailored to this ligase clade.

A blast search of the NCBI database with human Clp1 readily identified putative homologs in diverse archaeal genera: Aeropyrum, Archaeoglobus, Caldivirga, Hyperthermus, Ignicoccus, Methanocaldococcus, Methanopyrus, Pyrobaculum, Pyrococcus, Staphylothermus, Sulfolobus, Thermococcus, Thermofilum, and Thermoproteus. The archaeal Clp1 homologs vary in size from 351 to 439 amino acids. An alignment of the primary structures of the 361 amino acids Pyrococcus horikoshii Clp1 (hereafter PhoClp1) and human Clp1 (425 amino acids) highlights 113 positions of side-chain identity/similarity that includes the P-loop motif GxxxxGK(T/S) (Fig. 1). We report here the purification of PhoClp1, its characterization as a thermostable Pnk with a preference for RNA substrates, and demonstration of its RNA repair capacity in vivo.

\section{RESULTS AND DISCUSSION}

\section{Thermostable polynucleotide kinase activity of PhoClp1}

To assess what biochemical activities, if any, are associated with an archaeal Clp1 homolog, we produced in Escherichia coli wild-type PhoClp1 and two mutants: K49A and D73A. Lys49 is the defining P-loop lysine that contacts the phosphates of the NTP donor. Asp73 is the counterpart of T4 Pnk Asp35, an essential residue located near the polynucleotide $5^{\prime}$-OH terminus (Wang et al. 2002; Eastberg et al. 2004). Recombinant PhoClp1 proteins were produced as $\mathrm{His}_{10} \mathrm{Smt} 3$ fusions and isolated from soluble bacterial extracts by adsorption to Ni-agarose resin and elution with imidazole. The His ${ }_{10} \mathrm{Smt} 3 \mathrm{tag}$ was removed with the Smt3specific protease Ulp1 (Mossessova and Lima 2000) and the tag-less PhoClp1 proteins were separated from the tag by a second round of Ni-agarose chromatography. SDS-PAGE

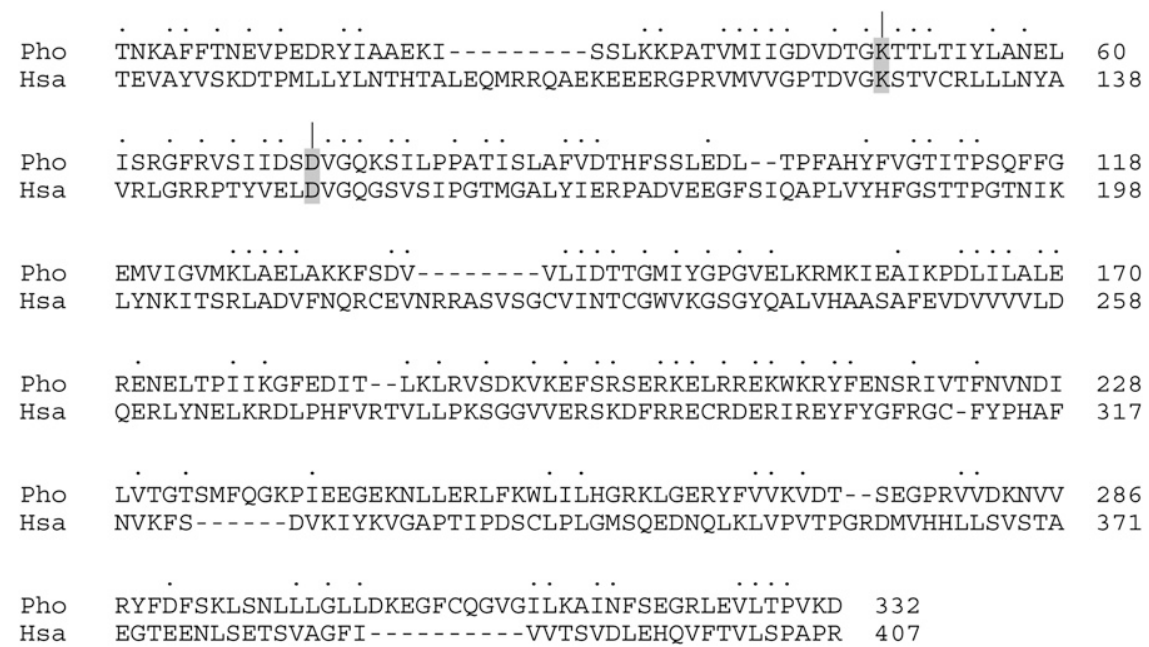

FIGURE 1. Primary structure similarity between human and archaeal Clp1. The amino acid sequence of $P$. horikoshii Clp1 (Pho) is aligned to the homologous polypeptide encoded by H. sapiens (Hsa). Gaps in the alignment are indicated by dashes. Positions of amino acid side chain identity or similarity are indicated by dots. The amino acids subjected to alanine substitution (Lys49 and Asp73) are highlighted and indicated by |. 
analysis highlighted the equivalent purity of the PhoClp1 preparations, which were enriched with respect to the 41kDa Clp1 polypeptide (Fig. 2A).

A polynucleotide kinase activity of wild-type PhoClp1 was demonstrated by incubating the protein with magnesium, $\left[\gamma^{32} \mathrm{P}\right] \mathrm{ATP}$ and a 24 -mer $5^{\prime}-\mathrm{OH}$ DNA oligonucleotide for $15 \mathrm{~min}$ at $55^{\circ} \mathrm{C}$. This resulted in label transfer from ATP to the 24-mer DNA, as gauged by denaturing PAGE and autoradiography. The extent of DNA phosphorylation was proportional to PhoClp1 concentration (Fig. 2B). From the slope of the titration curve, we estimated a turnover number of $3.4 \mathrm{~min}^{-1}$. The K49A mutation reduced kinase specific activity to $1 \%$ of the wild-type value; the D73A mutation abolished activity (Fig. 2B).

The PhoClp1 DNA kinase was active from pH 4.5 to 9.5 in Tris-acetate or Tris-HCl buffers (data not shown). DNA phosphorylation required a divalent cation and was optimal from $2 \mathrm{mM}$ to $20 \mathrm{mM} \mathrm{Mg}^{2+}$ (data not shown). The ${ }^{32} \mathrm{P}-\mathrm{DNA}$ product accumulated with time and the rate of the reaction increased with increasing concentrations of PhoClp1 (Fig. 2C). DNA kinase activity displayed a hyperbolic dependence on ATP concentration, with an apparent $K_{\mathrm{m}}$ of $16 \mu \mathrm{M}$ ATP and a $k_{\text {cat }}$ of $4.6 \mathrm{~min}^{-1}$ (Fig. 2D).

PhoClp1 was also active as a $5^{\prime}$-OH RNA kinase at $55^{\circ} \mathrm{C}$ with a 24-mer RNA oligonucleotide acceptor of the same nucleotide sequence as the DNA substrate (Fig. 3). RNA phosphorylation was optimal in Tris-acetate buffer from $\mathrm{pH} 4.5$ to 6.5 (data not shown); activity declined by about one-third in TrisHCl buffer from $\mathrm{pH} 7.0$ to 9.5 (data not shown). The K49A and
D73A mutations suppressed the RNA kinase activity (data not shown) to the same extent as the DNA kinase.

PhoClp1 RNA kinase activity was optimal between $55^{\circ} \mathrm{C}$ and $85^{\circ} \mathrm{C}$ and the enzyme maintained activity even at $95^{\circ} \mathrm{C}$ (Fig. 3). The DNA kinase activity was optimal between $55^{\circ} \mathrm{C}$ and $75^{\circ} \mathrm{C}$ and declined progressively at $85^{\circ} \mathrm{C}$ and $95^{\circ} \mathrm{C}$ (Fig. 3). Preheating the PhoClp1 preparation at $80^{\circ} \mathrm{C}$ for $60 \mathrm{~min}$ followed by quenching on ice had no effect on the kinase activity assayed at $55^{\circ} \mathrm{C}$ (data not shown). We conclude from these initial experiments that PhoClp1 is a bona fide Pnk enzyme with a P-loop active site and exceptional thermal stability.

\section{PhoClp1 preferentially phosphorylates 5'-OH RNA}

Human Clp1 has a strong preference for RNA as the phosphate acceptor (Weitzer and Martinez 2007). To see if this is the case for PhoClp1, we presented the kinase with an equimolar mixture of $24-\mathrm{mer} 5^{\prime}-\mathrm{OH}$ RNA and $5^{\prime}-\mathrm{OH}$ DNA substrates and gauged the distribution of phosphorylated products as a function of PhoClp1 concentration (Fig. 4). Control kinase reactions with T4 Pnk demonstrated equal labeling of the individual substrates and verified the differential electrophoretic mobility of the 24mer pRNA and pDNA strands (Fig. 4A). PhoClp1 displayed a sixfold preference for RNA phosphorylation at limiting enzyme concentrations (Fig. 4A). The specific activities under "competitive" conditions were $7.1 \mathrm{~min}^{-1}$ for RNA versus $1.2 \mathrm{~min}^{-1}$ for DNA (Fig. $4 \mathrm{~B}$ ).
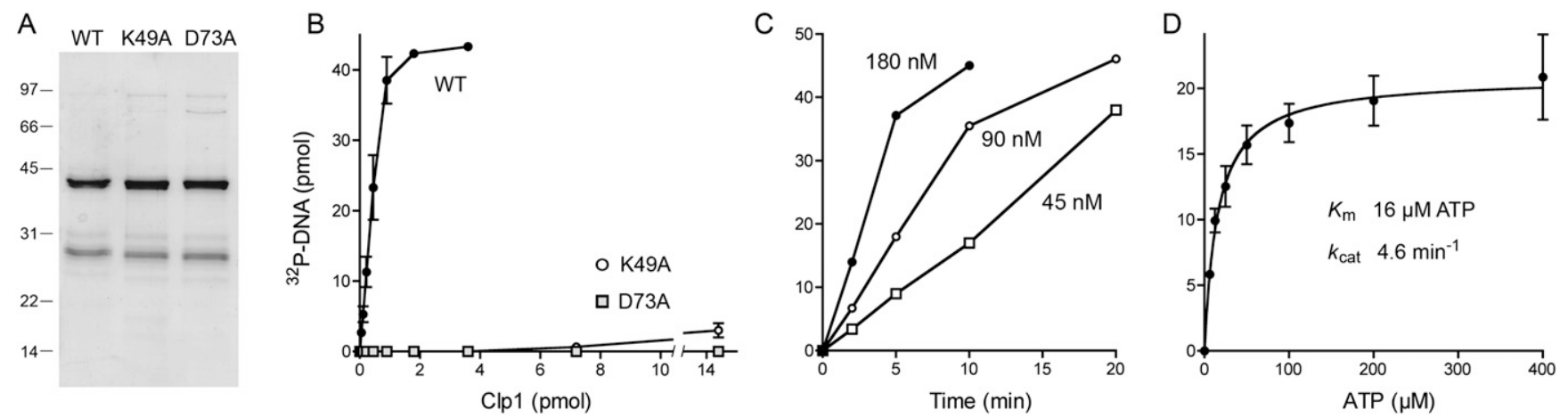

FIGURE 2. Polynucleotide kinase activity of PhoClp1. (A) PhoClp1 purification. Aliquots ( $3 \mu \mathrm{g})$ of tag-free wild-type PhoClp1 and the K49A and D73A mutants were analyzed by SDS-PAGE. The Coomassie blue stained gel is shown. The positions and sizes (kDa) of marker polypeptides are indicated on the left. The major $41 \mathrm{kDa}$ polypeptide corresponds to tag-free PhoClp1. We did not attempt to identify the $28 \mathrm{kDa}$ polypeptide, although we know it does not correspond to either the cleaved $\mathrm{His}_{10} \mathrm{Smt} 3$ tag or the Ulp1 protease, which migrate differently during SDS-PAGE. The $28-\mathrm{kDa}$ species was itself generated by Ulp1 cleavage of a larger polypeptide recovered during the first Ni-agarose purification step. Thus, we surmise that the $28-\mathrm{kDa}$ species is probably an N-terminal fragment of Clp1. (B) Kinase activity. Reaction mixtures $(10 \mu \mathrm{L})$ containing $50 \mathrm{mM}$ Tris-HCl (pH 7.5), $10 \mathrm{mM} \mathrm{MgCl}$, $500 \mu \mathrm{M}\left[\gamma^{32} \mathrm{P}\right]$ ATP, $5 \mu \mathrm{M}$ 24-mer 5'-OH DNA d(CACTATCGGAATAAGGGCGACACG), and wild-type or mutant PhoClp1 as specified were incubated for $15 \mathrm{~min}$ at $55^{\circ} \mathrm{C}$. The extent of DNA phosphorylation is plotted as a function of input PhoClp1. Each datum is the average of three separate titration experiments. Error bars denote the standard deviation. $(C)$ Kinetics. Reaction mixtures $(70$ $\mu \mathrm{L}$ ) containing $50 \mathrm{mM}$ Tris- $\mathrm{HCl}\left(\mathrm{pH}\right.$ 7.5), $10 \mathrm{mM} \mathrm{MgCl}_{2}, 500 \mu \mathrm{M}\left[\gamma^{32} \mathrm{P}\right] \mathrm{ATP}, 5 \mu \mathrm{M}$ 24-mer 5'-OH DNA and either 45, 90 , or 180 nM PhoClp1 as specified were incubated at $55^{\circ} \mathrm{C}$. Aliquots $(10 \mu \mathrm{L}$, containing 50 pmol of DNA ends) were withdrawn at the times specified and quenched immediately with EDTA/formamide. (D) ATP titration. Reaction mixtures $(10 \mu \mathrm{L})$ containing $50 \mathrm{mM}$ Tris- $\mathrm{HCl}(\mathrm{pH} 7.5), 10 \mathrm{mM} \mathrm{MgCl}, 5 \mu \mathrm{M}$ 24-mer 5'-OH DNA, $0.45 \mathrm{pmol} P h o \mathrm{Clp} 1$, and $\left[\gamma^{32} \mathrm{P}\right]$ ATP as specified were incubated for $10 \mathrm{~min}$ at $55^{\circ} \mathrm{C}$. The extent of DNA phosphorylation is plotted as a function of ATP concentration. Each datum is the average of three separate titration experiments. Error bars denote the standard deviation. $K_{\mathrm{m}}$ and $k_{\mathrm{cat}}$ were calculated in Prism by nonlinear regression curve fitting of the experimental data. 


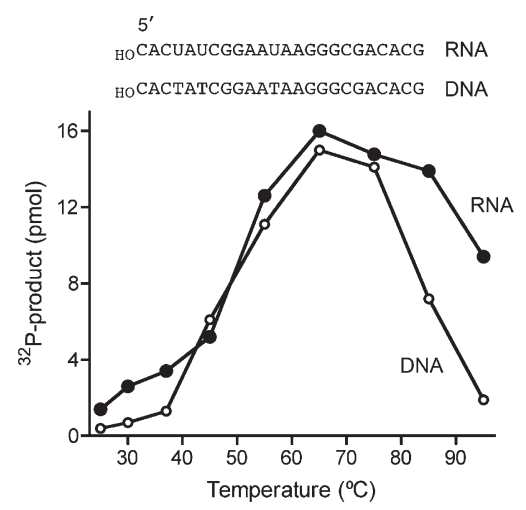

FIGURE 3. PhoClp1 is thermophilic. Reaction mixtures $(10 \mu \mathrm{L})$ containing $50 \mathrm{mM}$ Tris- $\mathrm{HCl}$ at $\mathrm{pH} 7.5$, (DNA kinase) or $50 \mathrm{mM}$ Trisacetate at $\mathrm{pH} 6.5$, (RNA kinase), $10 \mathrm{mM} \mathrm{MgCl}_{2}, 500 \mu \mathrm{M}\left[\gamma^{32} \mathrm{P}\right] \mathrm{ATP}, 5$ $\mu \mathrm{M}$ 24-mer $5^{\prime}-\mathrm{OH}$ DNA or $5^{\prime}-\mathrm{OH}$ RNA as shown, and $0.3 \mathrm{pmol}$ PhoClp1 were incubated for $15 \mathrm{~min}$ at the specified temperature. The reactions were initiated by adding PhoClp1 to preheated reaction mixtures. The extents of product formation are plotted as a function of reaction temperature.

\section{Effects of oligonucleotide chain length on RNA and DNA kinase activity}

PhoClp1 was reacted with an equimolar mixture of 30-mer, 20-mer, and 10-mer oligoadenylate RNA substrates and the distribution of phosphorylated products was assayed as a function of enzyme concentration (Fig. 5). Control kinase reactions with T4 Pnk demonstrated similar extents of labeling of the individual $\mathrm{r}(\mathrm{A})_{30}, \mathrm{r}(\mathrm{A})_{20}$, and $\mathrm{r}(\mathrm{A})_{10}$ substrates (Fig. 5A). PhoClp1 displayed little in the way of length preference at limiting enzyme concentrations and all three substrates were efficiently labeled at saturating enzyme (Fig. 5A). The specific activities under "competitive" conditions were $1.8,1.6$, and $1.2 \mathrm{~min}^{-1}$ for $\mathrm{rA}_{30}, \mathrm{rA}_{20}$, and $\mathrm{rA}_{10}$, respectively (Fig. $5 \mathrm{~B}$ ).

A similar analysis was performed with an equimolar mixtures of 40-mer, 30-mer, and 20-mer oligodeoxyadenylate DNA substrates (Fig. 6). Whereas PhoClp1 was equally adept at phosphorylating the $\mathrm{d}(\mathrm{A})_{40}$ and $\mathrm{d}(\mathrm{A})_{30}$ acceptors (specific activity $2 \mathrm{~min}^{-1}$ ), there was a twofold decrement in specific activity with $\mathrm{d}(\mathrm{A})_{20}\left(0.9 \mathrm{~min}^{-1}\right)$. The bias against phosphorylation of shorter DNA oligomers by PhoClp1 was more evident when PhoClp1 was presented with an equimolar mixture of 24-mer, 18-mer, and 12-mer hetero-oligomers of identical $5^{\prime}$-terminal sequence (Fig. 7A). The specific activities were $4.7 \mathrm{~min}^{-1}, 1.7 \mathrm{~min}^{-1}$, and $0.7 \mathrm{~min}^{-1}$, respectively (Fig. 7B). Shorter oligonucleotides were not tested.

\section{Increased ionic strength enhances the RNA preference of PhoClp1}

The RNA and DNA kinase reactions presented above were performed at low ionic strength. In the experiment shown in Figure 8A, we compared PhoClp1 activity with DNA and RNA substrates in the absence or presence of $250 \mathrm{mM}$
$\mathrm{NaCl}$. Increasing the ionic strength suppressed the DNA kinase activity with no adverse effect on RNA phosphorylation. Indeed, DNA kinase activity was inhibited progressively by increasing concentrations of $\mathrm{NH}_{4} \mathrm{Cl}, \mathrm{KCl}$, or $\mathrm{NaCl}$, resulting in $>95 \%$ inhibition at $250 \mathrm{mM} \mathrm{KCl}$ or $\mathrm{NaCl}$ and $87 \%$ inhibition at $250 \mathrm{mM} \mathrm{NH} \mathrm{NH}_{4} \mathrm{Cl}$ (Fig. 8C). By contrast, the RNA kinase activity was indifferent to up to $250 \mathrm{mM}$ monovalent salts (Fig. 8B).

\section{The PhoClp1 polynucleotide kinase reaction is reversible}

The Pnk enzymes of bacteriophages T4, KVP40, Omega, and Cjw1 catalyze the transfer of a polynucleotide $5^{\prime}$ phosphate to ADP to form ATP and a $5^{\prime}-\mathrm{OH}$ polynucleotide (van de Sande et al. 1973; Zhu et al. 2004). To assess if PhoClp1 can also catalyze the reverse of the kinase reaction, we incubated the enzyme for $15 \mathrm{~min}$ at $55^{\circ} \mathrm{C}$ with $5^{\prime}{ }^{32} \mathrm{P}$ labeled 24-mer RNA or DNA in the presence of ADP and $\mathrm{Mg}^{2+}$. This resulted in the formation of a ${ }^{32} \mathrm{P}$-ATP product
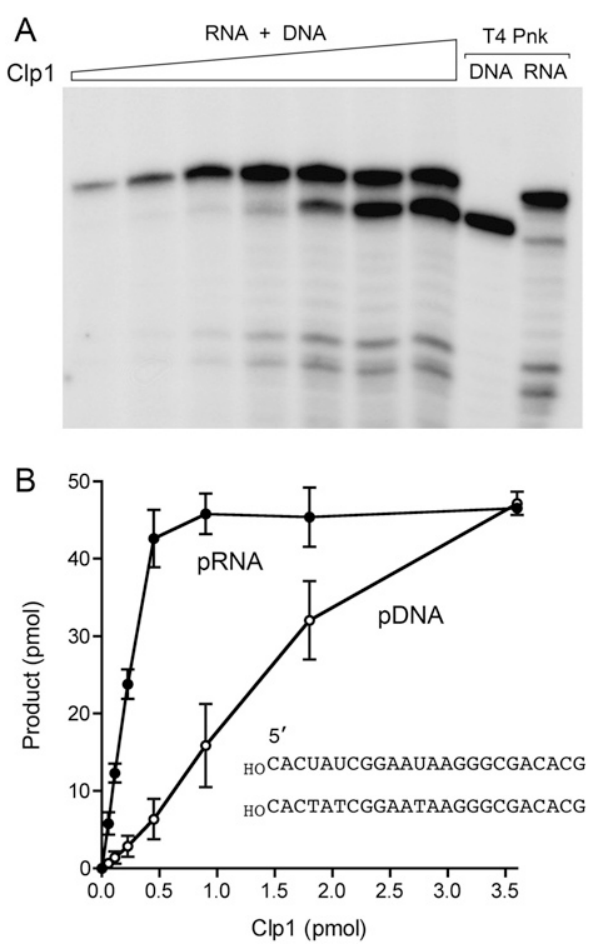

FIGURE 4. RNA is the preferred phosphate acceptor for PhoClp1. Reaction mixtures $(10 \mu \mathrm{L})$ containing $50 \mathrm{mM}$ Tris-acetate $(\mathrm{pH} \mathrm{6.5)}$, $10 \mathrm{mM} \mathrm{MgCl}_{2}, 500 \mu \mathrm{M}\left[\gamma^{32} \mathrm{P}\right] \mathrm{ATP}, 5 \mu \mathrm{M}$ each of 24 -mer $5^{\prime}-\mathrm{OH}$ DNA and RNA oligonucleotides (of equivalent sequences depicted in $B$ ), and PhoClp1 as specified in $B$ were incubated for $15 \mathrm{~min}$ at $55^{\circ} \mathrm{C}$. Control reactions contained $10 \mathrm{U}$ of T4 polynucleotide kinase (Pnk) plus either the DNA or RNA substrate. The products were analyzed by denaturing PAGE and visualized by autoradiography $(A)$. The extents of DNA and RNA phosphorylation were quantified by scanning the gel and are plotted as a function of input PhoClp1 in B. Each datum is the average of three separate titration experiments. Error bars denote the standard deviation. 

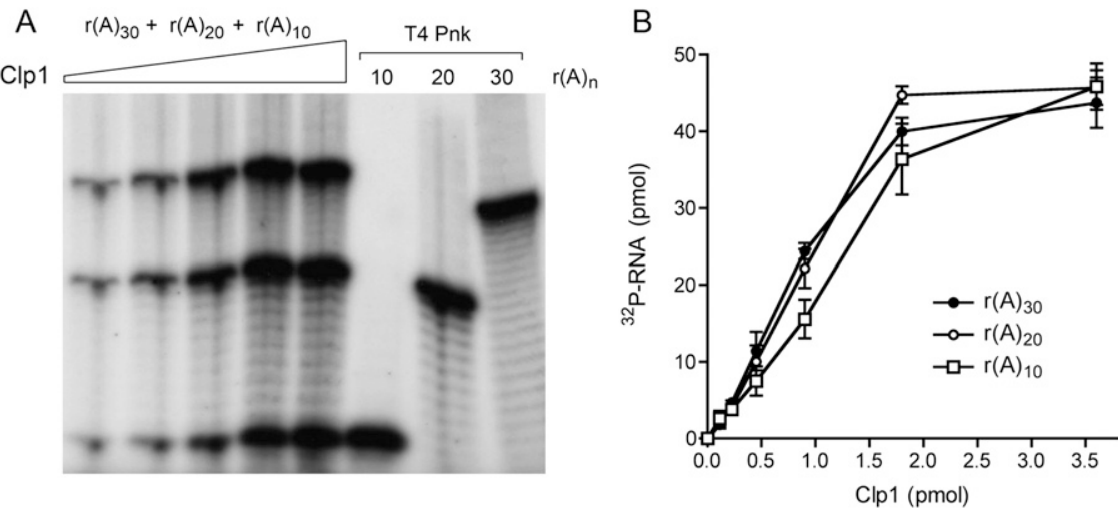

FIGURE 5. Effect of oligo(A) chain length on PhoClp1 kinase activity. Reaction mixtures (10 $\mu \mathrm{L})$ containing $50 \mathrm{mM}$ Tris-acetate $(\mathrm{pH} 6.5), 10 \mathrm{mM} \mathrm{MgCl}_{2}, 500 \mu \mathrm{M}\left[\gamma^{32} \mathrm{P}\right] \mathrm{ATP}, 5 \mu \mathrm{M}$ each of $5^{\prime}-\mathrm{OH}$ oligoadenylates $\mathrm{r}(\mathrm{A})_{30}, \mathrm{r}(\mathrm{A})_{20}$, and $\mathrm{r}(\mathrm{A})_{10}$, and increasing amounts of PhoClp1 as specified in $B$ were incubated for $15 \mathrm{~min}$ at $55^{\circ} \mathrm{C}$. Control reactions contained $10 \mathrm{U}$ of T4 Pnk plus the indicated $\mathrm{r}(\mathrm{A})_{\mathrm{n}}$ substrate. The products were analyzed by denaturing PAGE and visualized by autoradiography $(A)$. The extents of DNA and RNA phosphorylation were quantified by scanning the gel and are plotted as a function of input PhoClp1 in B. Each datum is the average of three separate titration experiments. Error bars denote the standard deviation. protein in Saccharomyces cerevisiae under the control of a constitutive promoter on a $2 \mu$ plasmid and asked whether PhoClp1 could replace the essential kinase activity of a cellular tRNA ligase. Specifically, we tested its ability to complement a lethal S701A mutation in the kinase active site of AtRNL (Wang et al. 2006) by using a plasmid shuffle assay. Yeast trlld strains carrying TRL1 on a CEN URA3 plasmid were cotransformed with a CEN TRP1 plasmid bearing AtRNL-S701A and a $2 \mu$ HIS3 plasmid expressing either the wildtype yeast Trl1 kinase-CPD domain (positive control) or wild-type PhoClp1. The empty HIS3 vector served as a negative control. AtRNL-S701A plus the empty vector was unable to sustain growth on medium containing the drug FOA (5fluoroorotic acid), which selects against that was resolved from the oligonucleotide by PEI-cellulose TLC (Fig. 9A). More than 90\% of the input polynucleotide $5^{\prime}-\mathrm{PO}_{4}$ was converted to ATP by PhoClp1. Any of the four common ribonucleoside diphosphates could serve as an acceptor (Fig. 9B). PhoClp1 mutants K49A and D73A were apparently inert in the reverse kinase reaction (Fig. 9B), signifying that the forward and reverse phosphoryl transfer steps rely on overlapping (if not identical) active site constituents. The reverse kinase reaction of PhoClp1 was optimal at $\mathrm{pH}$ 4.5-5.0 in Tris-acetate buffer (data not shown). Activity declined to $60 \%$ of the optimum in Trisacetate at $\mathrm{pH} 6.5,13 \%$ in Tris- $\mathrm{HCl}$ at $\mathrm{pH} 7.0$, and $1 \%$ in Tris- $\mathrm{HCl}$ at $\mathrm{pH} 9.5$ (data not shown).

The extent of phosphoryl transfer from ${ }^{32} \mathrm{P}$-DNA to ADP to form ${ }^{32} \mathrm{P}$-ATP was proportional to input PhoClp1 (Fig. 9C). From the slope of the titration curve, we estimated a turnover number of $0.05 \mathrm{~min}^{-1}$. ${ }^{32} \mathrm{P}$-ATP formation displayed a hyperbolic dependence on ADP concentration, with an apparent $K_{\mathrm{m}}$ of $21 \mu \mathrm{M}$ ADP and a $k_{\text {cat }}$ of 0.05 $\mathrm{min}^{-1}$ (Fig. 9D). Thus, the affinity of PhoClp1 for ADP in the reverse kinase reaction was similar to that for ATP in the forward reaction.

\section{PhoClp1 complements a lethal kinase-defective tRNA ligase mutation in yeast}

Yeast tRNA ligase ( $\operatorname{Trl} 1)$ consists of an N-terminal ligase domain, a central RNA kinase domain, and a C-terminal $2^{\prime}, 3^{\prime}$ cyclic phosphodiesterase (CPD) module. The plant tRNA ligase ortholog AtRNL (Arabidopsis thaliana RNA ligase) has a similar tripartite domain structure (Englert and Beier 2005; Wang et al. 2006) and is capable of performing all three essential splicing reactions in vivo in yeast cells that lack Trl1 (Wang et al. 2006). To query whether PhoClp1 can act as a tRNA splicing enzyme, we expressed the full-length PhoClp1 the CEN URA3 TRL1 plasmid. Growth on FOA was restored by yeast kinase-CPD, as expected. The salient finding was that PhoCLP1 complemented the lethal kinase mutation (Fig. 10).
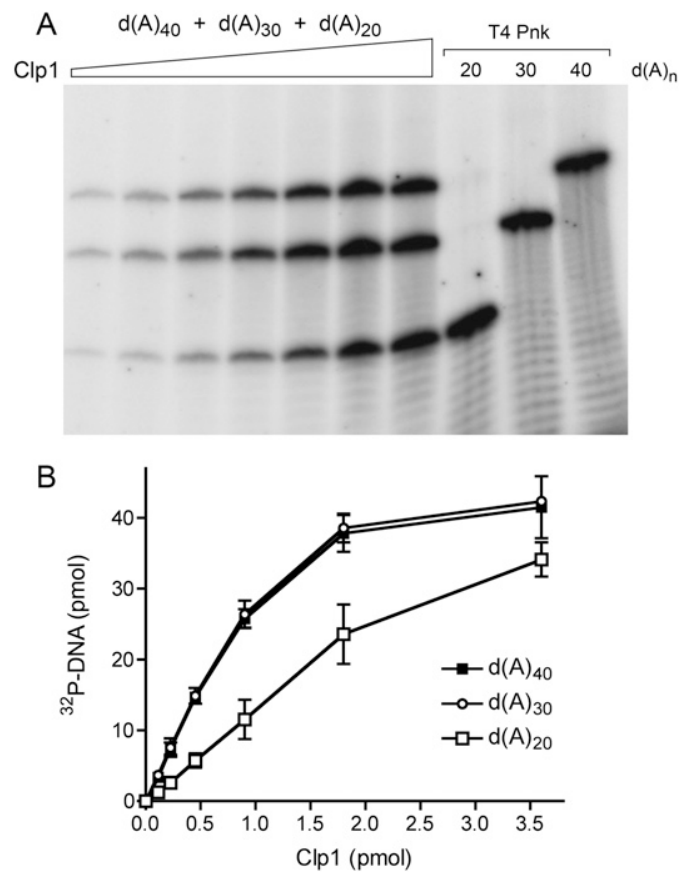

FIGURE 6. Effect of oligo(dA) chain length on PhoClp1 kinase activity. Reaction mixtures $(10 \mu \mathrm{L})$ containing $50 \mathrm{mM}$ Tris- $\mathrm{HCl}(\mathrm{pH} 7.5), 10$ $\mathrm{mM} \mathrm{MgCl}_{2}, 500 \mu \mathrm{M}\left[\gamma^{32} \mathrm{P}\right] \mathrm{ATP}, 5 \mu \mathrm{M}$ each of $5^{\prime}-\mathrm{OH}$ oligodeoxyadenylates $\mathrm{d}(\mathrm{A})_{40}, \mathrm{~d}(\mathrm{~A})_{30}$, and $\mathrm{d}(\mathrm{A})_{20}$, and increasing amounts of PhoClp1 as specified in $B$ were incubated for $15 \mathrm{~min}$ at $55^{\circ} \mathrm{C}$. Control reactions contained $10 \mathrm{U}$ of T4 Pnk plus the indicated $\mathrm{r}(\mathrm{A})_{\mathrm{n}}$ substrate. The products were analyzed by denaturing PAGE and visualized by autoradiography $(A)$. The extents of DNA and RNA phosphorylation PhoClp1 in B. Each datum is the average of three separate titration experiments. Error bars denote the standard deviation. were quantified by scanning the gel and are plotted as a function of input 

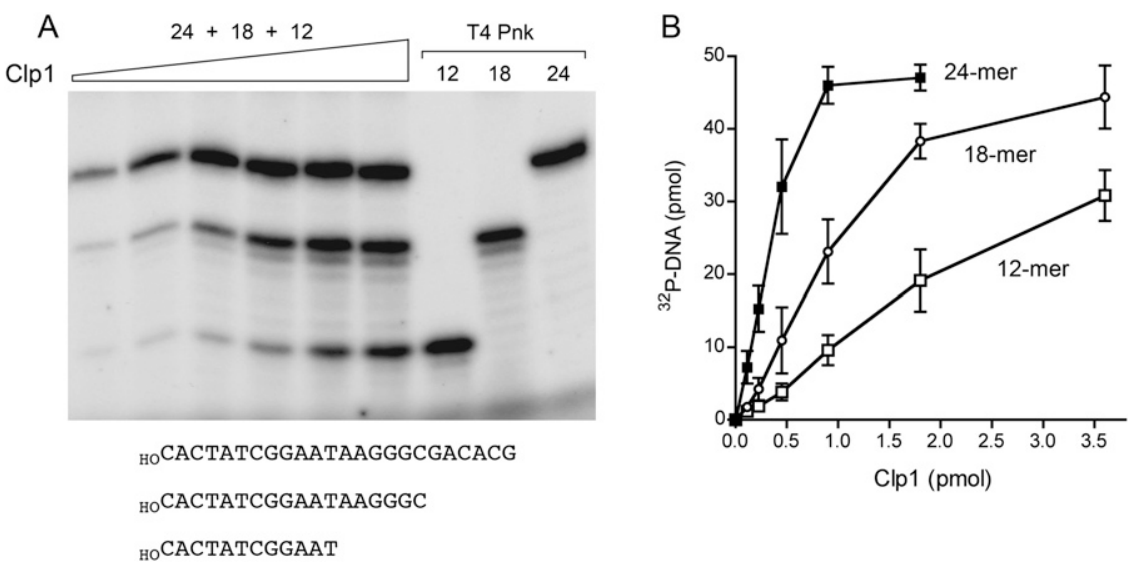

FIGURE 7. Effect of DNA length. Reaction mixtures $(10 \mu \mathrm{L})$ containing $50 \mathrm{mM}$ Tris- $\mathrm{HCl}$ (pH 7.5), $10 \mathrm{mM} \mathrm{MgCl}_{2}, 500 \mu \mathrm{M}\left[\gamma^{32} \mathrm{P}\right] \mathrm{ATP}, 5 \mu \mathrm{M}$ each of 24 -mer, 18-mer, and 12-mer 5'OH DNA oligonucleotides with identical $5^{\prime}$-sequences (depicted at the bottom of $A$ ), and increasing amounts of PhoClp1 (as specified in $B$ ) were incubated for $15 \mathrm{~min}$ at $55^{\circ} \mathrm{C}$. Control reactions contained $10 \mathrm{U}$ of T4 Pnk plus the indicated DNA substrate. The products were analyzed by denaturing PAGE and visualized by autoradiography $(A)$. The extents of DNA phosphorylation were quantified by scanning the gel and are plotted as a function of input PhoClp1 in B. Each datum is the average of three separate titration experiments. Error bars denote the standard deviation.

\section{Implications for Clp1 function, evolution, and praxis}

Here we provided biochemical and genetic evidence that archaeal Clp1 is an RNA 5' end healing enzyme in vitro and is capable of performing the RNA kinase step of yeast tRNA splicing in vivo. PhoClp1 is structurally and functionally homologous in this respect to the human RNA kinase Clp1 (Weitzer and Martinez 2007; Ramirez et al. 2008). By contrast, yeast Clp1 is unable to perform the analogous 5' RNA end healing reactions in vitro or in vivo (Ramirez et al. 2008). These results suggest that the ancestral Clp1 was an RNA kinase. We can speculate that the need to maintain a Clp1 kinase activity might have been relieved in budding yeast, a species that lacks an siRNA pathway, and clearly has another essential RNA kinase enzyme (in Trl1) that is dedicated to tRNA splicing. There is no obvious homolog of yeast or plant tRNA ligase in any metazoan proteome.

It is premature to speculate with conviction about the likely RNA substrates for PhoClp1 kinase or the physiology of putative archaeal RNA repair pathways, given that so little is known about RNA transactions in archaeal species. We mentioned above that the presumptive archaeal tRNA splicing pathway does not mandate an RNA kinase, but there are other instances of RNA end joining in Pyrococcus (Starotsina et al. 2004) that might involve a classical bacteriophage-type RNA ligation pathway. Pyrococcus and other archaea have a CRISPR system that relies on small processed RNAs to combat foreign DNAs (Barrangou et al. 2007; Brouns et al. 2008; Hale et al. 2008). An RNA kinase might be involved in maintenance of the ends of the CRISPR transcripts.
PhoClp1 is a highly thermostable Pnk enzyme; it is active at $80^{\circ} \mathrm{C}$ and withstands heating at that temperature for at least $60 \mathrm{~min}$. The T4-like $5^{\prime}$-kinase/ $3^{\prime}$ phosphatase enzyme from Rhodothermus marinus bacteriophage RM378 is active at elevated temperatures, but it loses activity after $1 \mathrm{~h}$ at $70^{\circ} \mathrm{C}$ (Blondal et al. 2005). Unlike the bifunctional T4type enzymes, PhoClp1 can be used to phosphorylate a DNA/RNA $5^{\prime}$ end without perturbing a preexisting $3^{\prime}$ phosphorylated terminus. PhoClp1 is especially suited to use as a reagent for RNA modification and labeling, insofar as it is selective for RNAs when confronted with a mixture of RNA and DNA substrates, and this selectivity is enhanced by performing the kinase reactions in high salt.
A
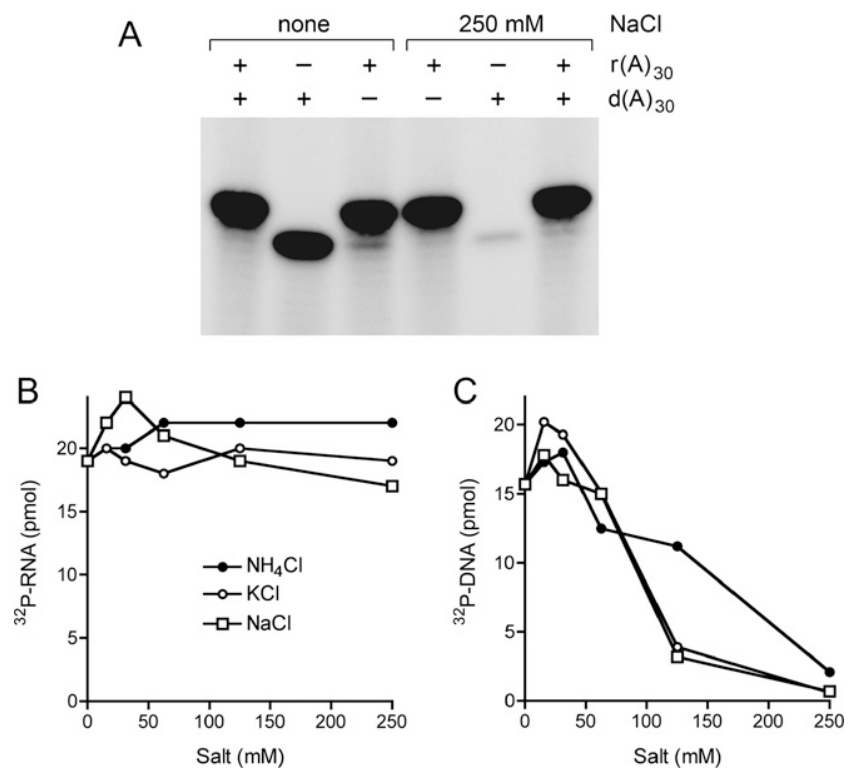

FIGURE 8. Effect of monovalent salts. (A) Reaction mixtures $(10 \mu \mathrm{L})$ containing $50 \mathrm{mM}$ Tris-acetate ( $\mathrm{pH} 6.5), 10 \mathrm{mM} \mathrm{MgCl}_{2}, 500 \mu \mathrm{M}$ $\left[\gamma^{32} \mathrm{P}\right] \mathrm{ATP}, 5 \mu \mathrm{M} 5^{\prime}-\mathrm{OH} \mathrm{d}(\mathrm{A})_{30}$ or $\mathrm{r}(\mathrm{A})_{30}$ as specified, $0.9 \mathrm{pmol}$ PhoClp1, and either no added salt or $250 \mathrm{mM} \mathrm{NaCl}$ as indicated were incubated for $15 \mathrm{~min}$ at $55^{\circ} \mathrm{C}$. The products were analyzed by denaturing PAGE and visualized by autoradiography. (B) Reaction mixtures $(10 \mu \mathrm{L})$ containing $50 \mathrm{mM}$ Tris-acetate $(\mathrm{pH} 6.5), 10 \mathrm{mM}$ $\mathrm{MgCl}_{2}, 500 \mu \mathrm{M}\left[\gamma^{32} \mathrm{P}\right] \mathrm{ATP}, 5 \mu \mathrm{M} 5^{\prime}-\mathrm{OH} \mathrm{r}(\mathrm{A})_{30}, 0.4 \mathrm{pmol}$ PhoClp1, and the indicated concentrations of $\mathrm{NH}_{4} \mathrm{Cl}, \mathrm{KCl}$, or $\mathrm{NaCl}$ were incubated at $55^{\circ} \mathrm{C}$ for $15 \mathrm{~min}$. The extents of product formation are plotted as a function of salt concentration. (C) Reaction mixtures (10 $\mu \mathrm{L})$ containing $50 \mathrm{mM}$ Tris- $\mathrm{HCl}(\mathrm{pH} 7.5), 10 \mathrm{mM} \mathrm{MgCl}_{2}, 500 \mu \mathrm{M}$ $\left[\gamma^{32} \mathrm{P}\right] \mathrm{ATP}, 5 \mu \mathrm{M} 5^{\prime}-\mathrm{OH} \mathrm{d}(\mathrm{A})_{30}, 0.45 \mathrm{pmol}$ PhoClp1, and and the indicated concentrations of $\mathrm{NH}_{4} \mathrm{Cl}, \mathrm{KCl}$, or $\mathrm{NaCl}$ were incubated at $55^{\circ} \mathrm{C}$ for $15 \mathrm{~min}$. The extents of product formation are plotted as a function of salt concentration. 


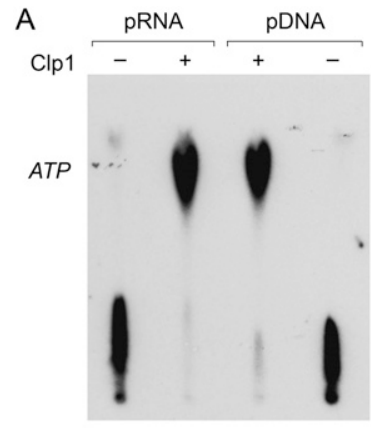

ṕcacuaucgganuaAgGgcGacacg ṕcActatcGgaAtaAgGgCGacacG

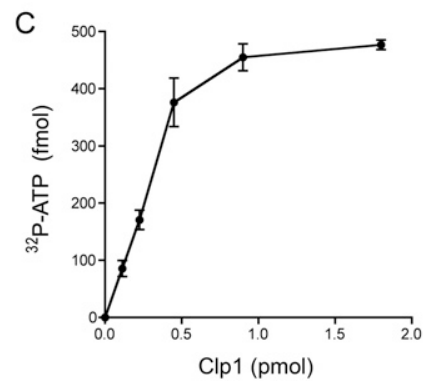

B

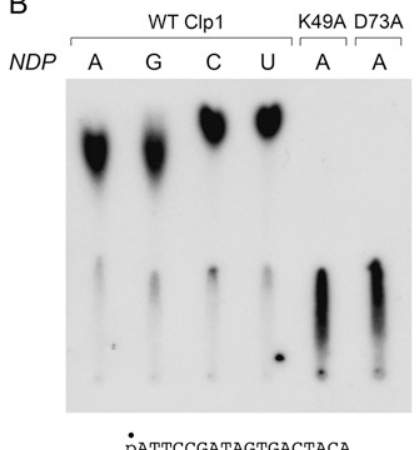

p̈attccGatagtGactaca

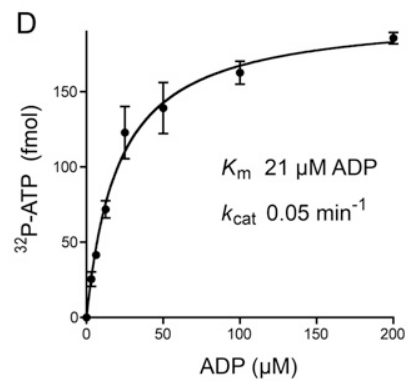

FIGURE 9. Reversal of the polynucleotide kinase reaction. (A) Reaction mixtures $(10 \mu \mathrm{L})$ containing $50 \mathrm{mM}$ Tris-acetate (pH 5.0), $10 \mathrm{mM} \mathrm{MgCl} 2,1 \mathrm{mM}$ ADP, $500 \mathrm{fmol}$ of $5^{\prime 32} \mathrm{P}$-labeled 24-mer DNA or RNA phosphoryl donor (depicted at the bottom), and 1.8 pmol PhoClp1 (where indicated by + ) were incubated for $15 \mathrm{~min}$ at $55^{\circ} \mathrm{C}$. The products were analyzed by PEI cellulose TLC in $2.5 \mathrm{M} \mathrm{LiCl}$. An autoradiograph of the TLC plate is shown. The position of the unlabeled ATP standard is indicated on the left. (B) Reaction mixtures $(10 \mu \mathrm{L})$ containing $50 \mathrm{mM}$ Tris-acetate $(\mathrm{pH} 5.0), 10 \mathrm{mM} \mathrm{MgCl}_{2}, 500$ fmol $5^{\prime}{ }^{32} \mathrm{P}$-labeled 18-mer DNA phosphoryl donor (depicted at the bottom), $1 \mathrm{mM}$ ADP, GDP, CDP, or UDP phosphoryl acceptor, and 1.8 pmol of wild-type of mutant PhoClp1 were incubated for $15 \mathrm{~min}$ at $55^{\circ} \mathrm{C}$. The products were analyzed by PEI cellulose TLC in $2.5 \mathrm{M}$ LiCl. An autoradiograph of the TLC plate is shown. (C) Reaction mixtures $(10 \mu \mathrm{L})$ containing $50 \mathrm{mM}$ Tris-acetate $(\mathrm{pH} 5.0), 10 \mathrm{mM}$ $\mathrm{MgCl}_{2}, 1 \mathrm{mM} \mathrm{ADP}$, and $500 \mathrm{fmol} 5^{\prime}{ }^{32} \mathrm{P}$-labeled 18-mer DNA, and PhoClp1 as specified were incubated for $15 \mathrm{~min}$ at $55^{\circ} \mathrm{C}$. The extent of ${ }^{32} \mathrm{P}$-ATP formation is plotted as a function of input PhoClp1. Each datum is the average of three separate titration experiments. Error bars denote the standard deviation. (D) Reaction mixtures $(10 \mu \mathrm{L})$ containing $50 \mathrm{mM}$ Tris-acetate (pH 5.0), $10 \mathrm{mM} \mathrm{MgCl}_{2}, 500 \mathrm{fmol} \mathrm{5}^{\prime}$ ${ }^{32} \mathrm{P}$-labeled 18-mer DNA, 0.3 pmol PhoClp1, and ADP as specified were incubated for $13 \mathrm{~min}$ at $55^{\circ} \mathrm{C}$. The extent of ${ }^{32} \mathrm{P}$-ATP formation is plotted as a function of ADP concentration. Each datum is the average of three separate titration experiments. Error bars denote the standard deviation. $K_{\mathrm{m}}$ and $k_{\text {cat }}$ were calculated in Prism by nonlinear regression curve fitting of the experimental data.

\section{MATERIALS AND METHODS}

\section{Recombinant PhoClp1}

A 1.1-kb DNA fragment spanning the PhoCLP1 ORF was amplified from total $P$. horikoshii genomic DNA by PCR with gene-specific primers designed to introduce BamHI sites immediately upstream of the ATG start codon and downstream of the stop codon. The PCR product was cleaved with BamHI and then inserted into pET28-His ${ }_{10} \mathrm{Smt} 3$ so that the PhoCLP1 gene was fused in-frame to a leader sequence encoding an $\mathrm{N}$-terminal
$\mathrm{His}_{10} \mathrm{Smt} 3$ polypeptide. Alanine mutations were introduced into the PhoCLP1 gene by two-stage PCR with mutagenic primers; mutated genes were inserted into pET28-His ${ }_{10} \mathrm{Smt} 3$. The inserts of all clones were sequenced to exclude the presence of unwanted mutations. The pET28-His ${ }_{10} \mathrm{Smt} 3-\mathrm{PhoClp} 1$ plasmids were transformed into Escherichia coli BL21(DE3). Single kanamycin-resistant colonies were inoculated into $\mathrm{LB}$ medium containing $0.05 \mathrm{mg} / \mathrm{mL}$ kanamycin and incubated at $37^{\circ} \mathrm{C}$ until $A_{600}$ reached $\sim 0.6$. The cultures ( $4 \mathrm{~L}$ for wild-type PhoClp1 and $1 \mathrm{~L}$ each for the K49A and D73A mutants) were then adjusted to $0.2 \mathrm{mM} \mathrm{IPTG}$ and $2 \%(\mathrm{v} / \mathrm{v})$ ethanol prior to incubation at $17^{\circ} \mathrm{C}$ for $16 \mathrm{~h}$ with constant shaking (250 rpm). Cells were harvested by centrifugation, and the pellets were stored at $-80^{\circ} \mathrm{C}$. All subsequent procedures were performed at $4^{\circ} \mathrm{C}$.

Cell pellets were thawed on ice and suspended in buffer A (50 $\mathrm{mM}$ Tris- $\mathrm{HCl}$ at $\mathrm{pH} 8.0,250 \mathrm{mM} \mathrm{NaCl}, 10 \%$ sucrose, $15 \mathrm{mM}$ imidazole) to attain $4 \%$ of the original culture volume. Lysozyme, PMSF, and Triton X-100 were added to final concentrations of $1 \mathrm{mg} / \mathrm{mL}, 0.2 \mathrm{mM}$, and $0.01 \%$, respectively. The lysates were sonicated to reduce viscosity and insoluble material was removed by centrifugation. The supernatants were withdrawn and applied to Ni-NTA-agarose columns (6 mL for wild-type PhoClp1 and 1.5 $\mathrm{mL}$ each for K49A and D73A) that had been equilibrated with buffer A. After washing with 10 column volumes of buffer A, the bound material was eluted in a stepwise fashion with buffer A containing 50, 100, 200, and $500 \mathrm{mM}$ imidazole. The protein compositions of the eluate fractions were monitored by SDSPAGE. The 200 and $500 \mathrm{mM}$ imidazole fractions containing His $_{10}$ Smt3-PhoClp1 were supplemented with the Smt3-specific protease, Ulp1 (Mossessova and Lima) to attain a His ${ }_{10} \mathrm{Smt3}$ Clp1:Ulp1 ratio of 200:1 The mixtures were dialyzed overnight against buffer B (50 mM Tris- $\mathrm{HCl}$ at $\mathrm{pH} 8.0,250 \mathrm{mM} \mathrm{NaCl}, 10 \%$ glycerol, $0.01 \%$ Triton X-100). The dialysates were applied to a fresh Ni-NTA agarose column equilibrated with buffer B. The tagfree PhoClp1 proteins were recovered in the flow through fractions. The PhoClp1 proteins were then dialyzed for $6 \mathrm{~h}$ against buffer $\mathrm{C}(50 \mathrm{mM}$ Tris- $\mathrm{HCl}$ at $\mathrm{pH} 8.0,50 \mathrm{mM} \mathrm{NaCl}, 10 \%$ glycerol, $0.01 \%$ Triton X-100, $2 \mathrm{mM} \beta$-mercaptoethanol, $2 \mathrm{mM}$ EDTA). Protein concentrations were determined by using the Bio-Rad dye

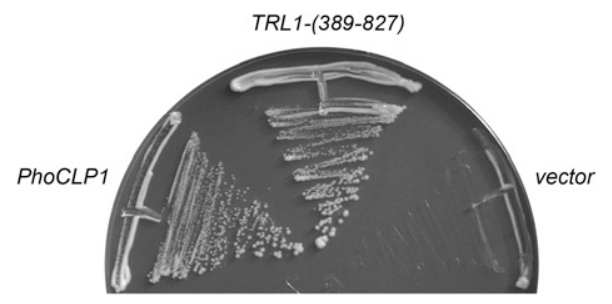

FIGURE 10. PhoClp1 can perform the $5^{\prime}$ end healing step of tRNA splicing in yeast. Yeast trl1 $\mathrm{p} 360-T R L 1$ (URA3 CEN) cells were cotransformed with a CEN TRP1 plasmid bearing AtRNL-S701A plus either: (1) p[CEN HIS3 TRL1-(389-827)] expressing the kinase-CPD domain of yeast tRNA ligase (positive control), (2) an empty $2 \mu$ HIS3 vector (negative control), or (3) $\mathrm{p}[2 \mu$ HIS3 PhoCLP1] expressing PhoClp1 under the control of the yeast TPI1 promoter. Trp ${ }^{+} \mathrm{His}^{+}$ transformants were selected at $30^{\circ} \mathrm{C}$ and then streaked on agar medium containing $0.75 \mathrm{mg} / \mathrm{mL} 5$-fluoroorotic acid. The plates were photographed after incubation for $4 \mathrm{~d}$ at $30^{\circ} \mathrm{C}$. 
reagent with bovine serum albumin as the standard. The yield of purified wild type PhoClp1 was $1.8 \mathrm{mg}$.

\section{Polynucleotide kinase assay}

Oligodeoxyribonucleotides were purchased from Fisheroligo. Oligoribonucleotides were purchased from Dharmacon. Standard reaction mixtures $(10 \mu \mathrm{L})$ containing either $50 \mathrm{mM}$ Tris $\mathrm{HCl}(\mathrm{pH}$ 7.5) or Tris acetate (pH 6.5), $10 \mathrm{mM} \mathrm{MgCl}_{2}, 500 \mu \mathrm{M}\left[\gamma^{32} \mathrm{P}\right]$ ATP, and $P$ hoClp 1 as specified were incubated for $15 \mathrm{~min}$ at $55^{\circ} \mathrm{C}$. The reactions were quenched by adding $10 \mu \mathrm{L}$ of $90 \%$ formamide, 50 mM EDTA, $0.005 \%$ bromophenol blue. The reaction products were analyzed by electrophoresis through a $15-\mathrm{cm}$ denaturing $15 \%$ or $22 \%$ polyacrylamide gel containing $7 \mathrm{M}$ urea in $45 \mathrm{mM}$ Tris-borate, $1.2 \mathrm{mM}$ EDTA. The ${ }^{32} \mathrm{P}$-labeled oligonucleotide products were visualized by autoradiography. The extents of label transfer were quantified by scanning of the gel with FUJIX BAS2500 imager.

\section{Reversal of polynucleotide kinase reaction}

Reaction mixtures $(10 \mu \mathrm{L})$ containing $50 \mathrm{mM}$ Tris-acetate ( $\mathrm{pH}$ 5.0),

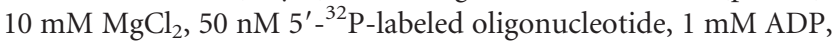
and PhoClp1 as specified were incubated for $15 \mathrm{~min}$ at $55^{\circ} \mathrm{C}$. The reactions were quenched by adding EDTA to a final concentration of $20 \mathrm{mM}$. An aliquot $(2 \mu \mathrm{L})$ of each reactions mixture was applied to a polyethyleneimine-cellulose TLC plate and then overlaid with $5 \mathrm{nmol}$ of unlabeled ATP, ADP, and AMP standards. Ascending TLC was performed with $2.5 \mathrm{M} \mathrm{LiCl}$. The nucleotide standards were visualized by UV auto fluorescence. The radiolabeled reaction products were visualized by autoradiography and quantified by scanning the plate with a FUJIX BAS2500 imager.

\section{ACKNOWLEDGMENTS}

This work was supported by NIH Grant GM42498. S.S. is an American Cancer Society Research Professor. R.J. is a predoctoral trainee in the Tri-Institutional Graduate Program in Chemical Biology of Cornell University.

Received December 1, 2008; accepted January 21, 2009.

\section{REFERENCES}

Amitsur, M., Levitz, R., and Kaufman, G. 1987. Bacteriophage T4 anticodon nuclease, polynucleotide kinase, and RNA ligase reprocess the host lysine tRNA. EMBO J. 6: 2499-2503.

Barrangou, R., Fremauzx, C., Deveau, H., Richards, M., Boyaval, P., Moineau, S., Romero, D.A., and Horvath, P. 2007. CRISPR provides acquired resistance against viruses in prokaryotes. Science 315: $1709-1712$.

Bernstein, N.K., Williams, R.S., Rakovszky, M.L., Cui, D., Green, R., Galicia, S., Koch, C.A., Cass, C.E., Durocher, D., Weinfeld, M., et al. 2005. The molecular architecture of the mammalian DNA repair enzyme, polynucleotide kinase. Mol. Cell 17: 657-670.

Blasius, M., Buob, R., Shevlev, I.V., and Hubscher, U. 2007. Enzymes involved in DNA ligation and end healing in the radioresistant bacterium Deinococcus radiodurans. BMC Mol. Biol. 8: 69.

Blondal, T., Hjorleifsdottir, S., Aevarsson, A., Fridjonsson, O.H., Skirnisdottir, S., Wheat, J.O., Hermannsdottir, A.G., Hreggvidsson, G.O., Smith, A.V., and Kristjansson, J.K. 2005. Characterization of a
5 '-polynucleotide kinase/3'-phosphatase from bacteriophage RM378. J. Biol. Chem. 280: 5188-5194.

Brooks, M.A., Meslet-Caliere, L., Graille, M., Kuhn, J., Blondeau, K., Myllykallio, H., and van Tilbeurgh, H. 2008. The structure of an archaeal homodimeric ligase which has RNA circularization activity. Protein Sci. 17: 1336-1345.

Brouns, S.J.J., Jore, M.M., Lundgren, M., Westra, E.R., Slijkhui, R.J.H., Snijders, A.P.L., Dickman, M.J., Makarova, K.S., Koonin, E.V., and van der Oost, J. 2008. Small CRISPR RNAs guide antiviral defense in prokaryotes. Science 321: 960-964.

Chiu, Y. and Rana, T.M. 2002. RNAi in human cells: Basic structural and functional features of small interfering RNA. Mol. Cell 10: 549-561.

de Vries, H., Rüegsegger, U., Hübner, W., Friedlein, A., Langen, H., and Keller, W. 2000. Human pre-mRNA cleavage factor IIm contains homologs of yeast proteins and bridges two other cleavage factors. EMBO J. 21: 5895-5904.

Eastberg, J.H., Pelletier, J., and Stoddard, B.L. 2004. Recognition of DNA substrates by bacteriophage T4 polynucleotide kinase. Nucleic Acids Res. 32: 653-660.

Englert, M. and Beier, H. 2005. Plant tRNA ligases are multifunctional enzymes that have diverged in sequence and substrate specificity from RNA ligases of other phylogenetic origins. Nucleic Acids Res. 33: 388-399.

Filipowicz, W. and Shatkin, A.J. 1983. Origin of splice junction phosphate in tRNAs processed by HeLa cell extract. Cell 32: 547-557.

Filipowicz, W., Konarska, M., Gross, H.J., and Shatkin, A.J. 1983. RNA 3 '-terminal phosphate cyclase activity and RNA ligation in HeLa cell extract. Nucleic Acids Res. 11: 1405-1418.

Galburt, E.A., Pelletier, J., Wilson, G., and Stoddard, B.L. 2002. Structure of a tRNA repair enzyme and molecular biology workhorse: T4 polynucleotide kinase. Structure 10: 1249-1260.

Gross, S. and Moore, C.L. 2001. Five subunits are required for reconstitution of the cleavage and polyadenylation activities of Saccharomyces cerevisiae cleavage factor I. Proc. Natl. Acad. Sci. 98: 6080-6085.

Hale, C., Kleppe, K., Termns, R.M., and Terns, M.P. 2008. Prokaryotic silencing (psi)RNAs in Pyrococcus furiosus. RNA 14: 2572-2579.

Ho, C.K. and Shuman, S. 2002. Bacteriophage T4 RNA ligase 2 (gp24.1) exemplifies a family of RNA ligases found in all phylogenetic domains. Proc. Natl. Acad. Sci. 99: 12709-12714.

Laski, F.A., Fire, A.Z., RajBhandary, U.L., and Sharp. P.A. 1983. Characterization of tRNA precursor splicing in mammalian extracts. J. Biol. Chem. 258: 11974-11980.

Martins, A. and Shuman, S. 2004. Characterization of a baculovirus enzyme with RNA ligase, polynucleotide $5^{\prime}$ kinase and polynucleotide 3' phosphatase activities. J. Biol. Chem. 279: 18220-18231.

Martins, A. and Shuman, S. 2005. An end-healing enzyme from Clostridium thermocellum with $5^{\prime}$ kinase, $2^{\prime}, 3^{\prime}$ phosphatase, and adenylyltransferase activities. RNA 11: 1271-1280.

Minvielle-Sebastia, L., Preker, P.J., Wiederkehr, T., Strahm, Y., and Keller, W. 1997. The major yeast poly(A)-binding protein is associated with cleavage factor IA and functions in pre-messenger RNA 3'-end formation. Proc. Natl. Acad. Sci. 94: 7897-7902.

Mossessova, E. and Lima, C.D. 2000. Ulp1-SUMO crystal structure and genetic analysis reveal conserved interactions and a regulatory element essential for cell growth in yeast. Mol. Cell 5: 865-876.

Nandakumar, J., Schwer, B., Schaffrath, R., and Shuman, S. 2008. RNA repair: An antidote to cytotoxic eukaryal RNA damage. Mol. Cell 31: 278-286.

Noble, C.G., Beuth, B., and Taylor, I.A. 2007. Structure of a nucleotide-bound Clp1-Pcf11 polyadenylation factor. Nucleic Acids Res. 35: 87-89.

Novogrodsky, A. and Hurwitz, J. 1966. The enzymatic phosphorylation of ribonucleic acid and deoxyribonucleic acid: Phosphorylation at 5'-hydroxyl termini. J. Biol. Chem. 241: 2923-2932.

Novogrodsky, A., Tal, M., Traub, A., and Hurwitz, J. 1966. The enzymatic phosphorylation of ribonucleic acid and deoxyribonucleic 
acid: Further properties of the $5^{\prime}$-hydroxyl polynucleotide kinase. J. Biol. Chem. 241: 2933-2943.

Nykänen, A., Haley, B., and Zamore, P.D. 2001. ATP requirements and small interfering RNA structure in the RNA interference pathway. Cell 107: 309-321.

Pascal, J.M. 2008. DNA and RNA ligases: Structural variations and shared mechanisms. Curr. Opin. Struct. Biol. 18: 96-105.

Ramirez, A., Shuman, S., and Schwer, B. 2008. Human RNA 5'-kinase (hClp1) can function as a tRNA splicing enzyme in vivo. RNA 14: 1737-1745.

Richardson, C.C. 1965. Phosphorylation of nucleic acid by an enzyme from T4 bacteriophage-infected Escherichia coli. Proc. Natl. Acad. Sci. 54: 158-165.

Salgia, S.R., Singh, S.J., Gurha, P., and Gupta, R. 2003. Two reactions of Haloferax volcanii RNA splicing enzymes: Joining of exons and circularization of introns. RNA 9: 319-330.

Schwer, B., Sawaya, R., Ho, C.K., and Shuman, S. 2004. Portability and fidelity of RNA-repair systems. Proc. Natl. Acad. Sci. 101: 2788-2793.

Shuman, S. and Hurwitz, J. 1979. 5' Hydroxyl polyribonucleotide kinase from HeLa cell nuclei. J. Biol. Chem. 254: 10396-10404.

Starotsina, N.G., Marshburn, S., Johnson, L.S., Eddy, S.R., Terns, R.M., and Terns, M.P. 2004. Circular box C/D RNAs in Pyrococcus furiosus. Proc. Natl. Acad. Sci. 101: 14097-14101.

Stevens, A. 2001. 5'-Exoribonuclease 1: Xrn1. Methods Enzymol. 342: 251-259.

Torchia, C., Takagi, Y., and Ho, C.K. 2008. Archaeal RNA ligase is a homodimeric protein that catalyzes intramolecular ligation of single-strand RNA and DNA. Nucleic Acids Res. 36: 6218-6227. van de Sande, J.H., Kleppe, K., and Khorana, H.G. 1973. Reversal of bacteriophage T4 induced polynucleotide kinase action. Biochemistry 12: 5050-5055.

Wang, L.K. and Shuman, S. 2001. Domain structure and mutational analysis of T4 polynucleotide kinase. J. Biol. Chem. 276: 2686826874.

Wang, L.K. and Shuman, S. 2002. Mutational analysis defines the 5' kinase and $3^{\prime}$ phosphatase active sites of T4 polynucleotide kinase. Nucleic Acids Res. 30: 1073-1080.

Wang, L.K., Lima, C.D., and Shuman, S. 2002. Structure and mechanism of T4 polynucleotide kinase-An RNA repair enzyme. EMBO J. 21: 3873-3880.

Wang, L.K., Schwer, B., Englert, M., Beier, H., and Shuman, S. 2006. Structure-function analysis of the kinase-CPD domain of yeast tRNA ligase (Trl1) and requirements for complementation of tRNA splicing by a plant Trll homolog. Nucleic Acids Res. 34: 517-527.

Weitzer, S. and Martinez, J. 2007. The human RNA kinase hClp1 is active on $3^{\prime}$ transfer RNA exons and short interfering RNAs. Nature 447: 2222-2226.

Zhu, H., Yin, S., and Shuman, S. 2004. Characterization of polynucleotide kinase/phosphatase enzymes from mycobacteriophages Omega and Cjw1 and vibriophage KVP40. J. Biol. Chem. 279: 26358-26369.

Zillman, M., Gorovsky, M.A., and Phizicky, E.M. 1991. Conserved mechanism of tRNA splicing in eukaryotes. Mol. Cell. Biol. 11: 5410-5416.

Zofallova, L., Guo, Y., and Gupta, R. 2000. Junction phosphate is derived from the precursor in the tRNA spliced by the archaeon Haloferax volcanii cell extract. RNA 6: 1019-1030. 

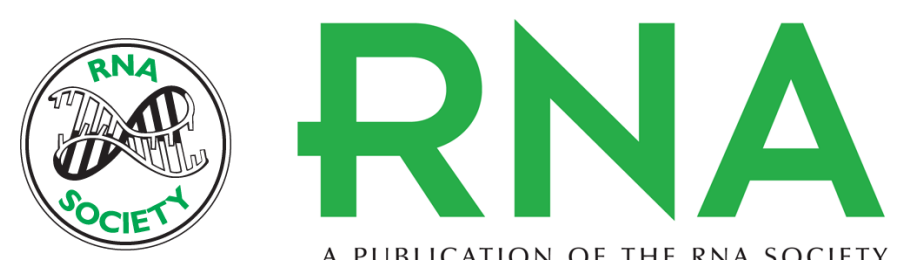

A PUBLICATION OF THE RNA SOCIETY

\section{Characterization of a thermostable archaeal polynucleotide kinase homologous to human Clp1}

Ruchi Jain and Stewart Shuman

RNA 2009 15: 923-931 originally published online March 19, 2009

Access the most recent version at doi:10.1261/rna.1492809

\section{References This article cites 45 articles, 23 of which can be accessed free at: http://rnajournal.cshlp.org/content/15/5/923.full.html\#ref-list-1}

\section{License}
Email Alerting Receive free email alerts when new articles cite this article - sign up in the box at the Service top right corner of the article or click here.

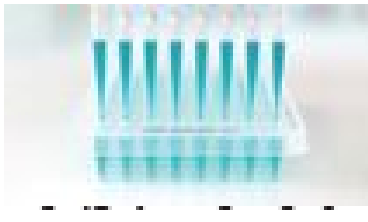

\section{Providing Precise Solutions for} your research.

To subscribe to $R N A$ go to:

http://rnajournal.cshlp.org/subscriptions 